The $3^{\text {rd }}$ Conf. of SSFOP "Recent Techniques in Ornamental Plants Scope", Cairo, Egypt, 26/2/2017

Scientific J. Flowers \& Ornamental Plants

www.ssfop.com/journal

ISSN: 2356-7864

\title{
THE ROLE OF HUMIC AND AMINO ACIDS IN IMPROVING GROWTH AND QUALITY OF PASPALUM TURF
}

\author{
Boshra A. El-Sayed", S.M. Shahin ${ }^{* *}$, T.M. Noor El-Deen ${ }^{*}$ and Hanan G.H. El-Fadaly ${ }^{*}$ \\ * Ornamental Plants and Landscape Gardening Res. Dept., Hort. Res. Inst., ARC, Giza, Egypt. \\ ** Botanical Gardens Res. Dept., Hort Res. Inst., ARC, Giza, Egypt.
}

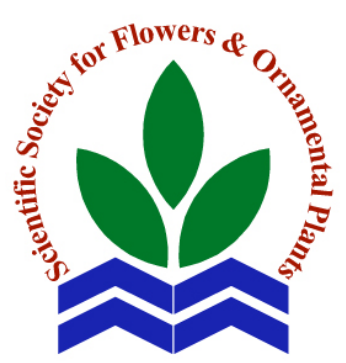

Scientific J. Flowers \& Ornamental Plants, 4(1):7-14 (2017).

Received: 20/12/2016

Accepted: $10 / 1 / 2017$

ABSTRACT: A field experiment was conducted at the nursery of Hort. Res. Inst., ARC., Giza, Egypt during 2014 and 2015 seasons to study the effect of spraying with humic acid at 0,5 and $10 \mathrm{ml} / \mathrm{l}$ and adding mixture of amino acids as soil drench at 0,1 and $2 \mathrm{~g} / \mathrm{pot}$ individually or in combinations on growth, covering rate (\%) and chemical composition of seashore paspalum (Paspalum vaginatum, Swartz.) plants grown in 40-cm-diameter plastic pots filled with sand medium.

The obtained results showed that all treatments caused improvement in plant height, covering rate, number of plants/pot and herb fresh and dry weights compared with control, also, chemical results of chlorophyll a, b and carotenoids content in the leaves and total sugars content in the herb. The best treatments used resulted from the combining between humic acid at $10 \mathrm{ml} / \mathrm{l}$ and mixture of amino acids at $2 \mathrm{~g} /$ pot which recorded the highest means.

Hence, in order to get the best growth and quality of paspalum plants, it could be recommended to spray with humic acid at $10 \mathrm{ml} / \mathrm{l}$ and adding a mixture of amino acids as soil drench at $2 \mathrm{~g} /$ pot six times with one month interval.

Key words: Paspalum vaginatum Swartz, humic acid, covering rate percentage, chemical composition.

\section{INTRODUCTION}

The importance of lawns, as the major part of gardens and public grounds, as well as the basis of landscape design is doubtless now well known. Many types of amenity grasses are now widely used for greening the lawns all over the year. Among them may be seashore Paspalum (Paspalum vaginatum, Swartz.) that belongs to Fam. Graminae. It is a succulent warm-season turf type grasses, but it retains a healthy appearance all yeararound, unlike Bermudagrass that tend to go off-colour during cooler months and short days (Huxley et al., 1992). It is easily propagated by cuttings and pre-prepared rolls, and fast spreads with lateral growing stems called stolons. It makes an attractive perennial turf in tropical and subtropical areas and can tolerate irrigation water with high salinity levels, withstand mowing, treading, as well as wear and tear (Morton, 1974).

In this regard, Hunter and Butler (2005) reported that humic acid significantly increased fresh and dry weights of Agrostis stolonifera herb with improving leaf colour and $\mathrm{P}$ content. Nutrients leaching was also minimized when humic acid, was applied. Likewise, Muller and Kussow (2005) mentioned that humic acid greatly improved 
colour and density of creeping bentgrass and increased soil microbial activity. On tifway bermudagrass, El-Sayed et al. (2008) revealed that actosol (a humic acid NPK liquid fertilizer) at $20 \mathrm{ml} / \mathrm{l}$ as a foliar spray significantly increased plant height, density, No. plants $/ \mathrm{m}^{2}$ as well as herb fresh and dry weights. A similar trend was also gained concerning chlorophyll a, b and carotenoids content in the leaves, and the percentages of total carbohydrates, $\mathrm{N}, \mathrm{P}$ and $\mathrm{K}$ in the herb.

Many researchers examined the influence of amino acids on improving all characters of the plant such as Abd El-Aziz et al. (2009), Hashish et al. (2015) and ElNagar et al. (2013). Amino acid as organic nitrogenous compounds are the building block in the process of protein synthesis (Smith, 1982), and can affect plant growth and development through their influence on IAA and GA biosynthesis. Also, amino acids may play an important role in plant metabolism and protein assimilation which are necessary for cell formation and consequently increase fresh and dry weights (Phillips, 1971; Russel, 1982 and Walter and Nawacki, 1987).

This trial aims to find out the role of spraying with humic acid and amino acids, alone or in combinations, in improving growth, colour, and performance of seashore Paspalum turf grass.

\section{MATERIALS AND METHODS}

Two pot experiments were performed at the Nursery of Hort. Res. Inst., ARC, Giza, Egypt through the two consecutive seasons of 2014 and 2015 to detect the response of seashore Paspalum grass to foliar spraying with humic acid and amino acids.

So, pieces from prepared rolls of seashore Paspalum (Paspalum vaginatum, Swartz.) at a diameter of $10 \mathrm{~cm}$ (their fresh weights ranged between 40-45 g) were carefully taken and planted on March, $1^{\text {st }}$ for each season in the center of 40-cm-diameter plastic pots filled with sand. The physical and chemical analyses of the used sand in both seasons are shown in Table (a). These pieces were planted in the soil and were then daily irrigated with $250 \mathrm{ml}$ of a tap water/pot during the first two weeks after planting. The pots were afterwards irrigated once every two days with $400 \mathrm{ml}$ of a tap water/pot throughout the course of this study.

After one month from planting (on April, $1^{\text {st }}$ ), the following fertilization treatments were monthly applied; humic acid as a foliar spray and amino acid as soil drench till the first of September (6 times) for each season:

- No fertilization, referred to as control.

- A humic acid NPK (10:10:10) liquid organic fertilizer (Actosol ${ }^{\circledR}$ ) was added after each cut at the rate of $0,5,10 \mathrm{ml} / \mathrm{l}$. The constituents of actosol were determined and illustrated in Table (b).

- Amino acid mixture (extract containing a mixture of amino acids, organic nitrogen, and potassium oxide was added as soil drench monthly after each cut at the rates of 0,1 and $2 \mathrm{~g} /$ pot the components of amino acids were measured and expressed in Table (c).

Table a. Some physical and chemical properties of the used sand during 2014 and 2015 seasons.

\begin{tabular}{|c|c|c|c|c|c|c|c|c|c|c|c|c|c|c|c|}
\hline \multirow{2}{*}{ : } & \multirow[b]{2}{*}{ 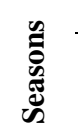 } & \multicolumn{4}{|c|}{ Particle size distribution (\%) } & \multirow[b]{2}{*}{ S.P. } & \multirow[b]{2}{*}{$\begin{array}{c}E C \\
(d S / m)\end{array}$} & \multirow[b]{2}{*}{ pH } & \multicolumn{4}{|c|}{ Cations (meq/l) } & \multicolumn{3}{|c|}{ Anions (meq/l) } \\
\hline & & $\begin{array}{c}\text { Coarse } \\
\text { sand }\end{array}$ & $\begin{array}{l}\text { Fine } \\
\text { sand }\end{array}$ & Silt & Clay & & & & $\mathrm{Ca}++$ & Mg++ & $\mathrm{Na}+$ & $\mathbf{K}+$ & $\mathrm{HCO}_{3}$ & $\mathrm{Cl}^{-}$ & $\mathrm{SO}_{4}$ \\
\hline \multirow{2}{*}{ "ָ } & 2014 & 89.03 & 2.05 & 0.40 & 8.52 & 23.01 & 3.56 & 7.90 & 7.50 & 1.63 & 33.60 & 0.50 & 3.20 & 22.00 & 18.03 \\
\hline & 2015 & 84.76 & 6.29 & 1.50 & 7.45 & 21.87 & 3.71 & 7.80 & 19.42 & 8.33 & 7.20 & 0.75 & 1.60 & 7.80 & 26.30 \\
\hline
\end{tabular}


Table b. Main characteristics of the used liquid organic fertilizer during the two seasons.

\begin{tabular}{|c|c|c|c|c|c|}
\hline Components & Value & Components & Value & Components & Value \\
\hline Humic acid (\%) & 2.9 & EC(dS/m) & 59.30 & B (ppm) & 70.00 \\
\hline Organic matter/total solids (\%) & 42.51 & N (\%) & 10.00 & Fe (ppm) & 900.00 \\
\hline Total H.A./total solids & 165.80 & $\mathbf{P}(\%)$ & 10.00 & Mn (ppm) & 90.00 \\
\hline Organic carbon (\%) & 24.65 & K (\%) & 10.00 & Zn (ppm) & 90.00 \\
\hline $\mathrm{C} / \mathrm{N}$ ratio & 2.46 & Ca (\%) & 0.06 & Cu (ppm) & 90.00 \\
\hline pH & 8.20 & $\operatorname{Mg}(\%)$ & 0.05 & & \\
\hline
\end{tabular}

Table c. The main components of the used amino acid during the two seasons.

\begin{tabular}{llll}
\hline Amino Acids & Percentage (\%) & Amino Acids & Percentage (\%) \\
\hline Aspartic & 3.29 & Lysin & 1.75 \\
Tyrosine & 0.52 & Arginine & 4.64 \\
Gluamic & 8.18 & Histidine & 0.56 \\
Glycin & 2.03 & Proline & 3.96 \\
Alanine & 2.26 & Phenyl alanine & 0.99 \\
Valine & 2.51 & Serine & 4.99 \\
Leucine & 2.03 & Threonine & 3.57 \\
\hline
\end{tabular}

\section{The treatments were as follow:}

1. Control.

2. Humic acid at $5 \mathrm{ml} / \mathrm{l}$.

3. Humic acid at $10 \mathrm{ml} / \mathrm{l}$.

4.Amino acids at $1 \mathrm{~g} /$ pot.

5.Amino acids at $2 \mathrm{~g} / \mathrm{pot}$.

6. Humic acid at 5 and $10 \mathrm{ml} / \mathrm{l}$ was combined with each level of amino acid to form 4 combination treatments as follows:

a. Humic acid at $5 \mathrm{ml} / \mathrm{l}+$ amino acids at $1 \mathrm{~g} /$ pot.

b. Humic acid at $5 \mathrm{ml} / \mathrm{l}+$ amino acids at 2 g/pot.

c . Humic acid at $10 \mathrm{ml} / \mathrm{l}+$ amino acids at $1 \mathrm{~g} /$ pot.

d. Humic acid at $10 \mathrm{ml} / \mathrm{l}+$ amino acids at $1 \mathrm{~g} /$ pot.

After two months from planting (on May, $1^{\text {st }}$ ), the first cut was handly done with very sharp stainless steel cutter leaving stubbles with 1 inch long. Other four cuts were carried out monthly thereafter. The pots were arranged in a completely randomized design (Mead et al., 1993) with three replicates for each treatment, as each replicate contained five pots.

Before each cut in the two seasons, plant height $(\mathrm{cm})$ was recorded, while number of plants/pot and fresh and dry weights (g) of the resulted herb after mowing were monitored after each cut. Moreover, the covering rate as percentage (density \%) was determined by using a wooden quadrate $(10 \times 10 \mathrm{~cm})$ called a gird, the gird divided in to 25 squares by cross-string, so that each square was $4 \%$ of the total area of this gird. The gird was dropped at random 5 times on the plot (turf). By carful estimation of number of the squares occupied by grass species, the percentage of covered area was determined (Mahdi, 1953).

However, means of each parameter mentioned above in the five taken cuts were collected and expressed in the tables as an average for all cuts. In fresh leaf samples taken from the last cut, photosynthetic pigments content (chlorophyll a, b and carotenoids, as mg/g f.w.) was measured 
according to the method described by Moran (1982), while in dry samples taken also from the herb of last cut, the percentage of total sugars (Herbert et al., 1976), as well as total indoles and total phenols (A.O.A.C., 1990) as $\mathrm{mg} / 100 \mathrm{~g}$ f.w. were assessed. The obtained data were statistically analyzed according to SAS Program (1994) using Duncan's Multiple Range Test (1955) for elucidating the significant differences among means of various treatments.

\section{RESULTS AND DISCUSSION}

\section{Effect of Humic acid and Amino acid treatments on:}

\section{Vegetative growth parameters:}

From data averaged in Tables (1) and (2), it could be concluded that all individual humic acid and amino acid treatments clearly improved all vegetative traits of seashore Paspalum plants (expressed as plant height $(\mathrm{cm})$, covering rate (\%), No. plants/pot and fresh and dry weights (g) of herb) with significant differences when compared to control in most cases of both seasons.

The combining between humic acid and amino acids induced an additional improvement in all parameters mentioned before, with the superiority of the combination between humic acid at $10 \mathrm{ml} / \mathrm{l}$ and amino acids at $2 \mathrm{~g} / \mathrm{pot}$, which gave, in general the tallest plants, the best coverage, the highest number of plants/pot and the heaviest fresh and dry weights over all other individual and combined treatments in the two seasons.

This may be attributed to the role of both humic acid in increasing the availability of nutrients in the soil through influences on soil microbial activity, besides it contains NPK and some micronutrients necessary for good growth (Dorer and Peacock, 1997), and amino acids which strengthen the immunity system of the plant and reduces the harmful effect of diseases. Moreover, it may play a role in balancing the hormonal control inside the plants, and so enhances the vegetative and root growth (Kim et al., 1991).

The aforementioned results are in accordance with those attained by Canaway (1992) on Lolium perenne cv. Loretta, Hunter and Butler (2005) on Agrostis stolonifera, El-Sayed et al. (2008) on Tifway Bermudagrass and Bettoni et al. (2009) on Kalanchoe.

\section{Chemical composition:}

Data in Table (3) exhibit that spraying of humic acid and amino acids, individually or in combination caused a significant increment in the leaf content of chlorophyll a, b and carotenoids (mg/g f.w.) over control plants with few exceptions in the two seasons. A similar trend was also attained concerning total sugars content (mg/g d.w.),

Table 1. Effect of humic acid and amino acids on plant height, covering rate and number of plants/pot of Paspalum vaginatum Swartz. plants during 2014 and 2015 seasons.

\begin{tabular}{lcccccc}
\hline \multirow{2}{*}{ Treatments } & \multicolumn{2}{c}{ Plant height (cm) } & \multicolumn{2}{c}{ Covering rate (\%) } & \multicolumn{2}{c}{ No. plants/pot } \\
& $\mathbf{2 0 1 4}$ & $\mathbf{2 0 1 5}$ & $\mathbf{2 0 1 4}$ & $\mathbf{2 0 1 5}$ & $\mathbf{2 0 1 4}$ & $\mathbf{2 0 1 5}$ \\
\hline Control & $10.15 \mathrm{~h}$ & $10.65 \mathrm{~g}$ & $43.05 \mathrm{~g}$ & $49.28 \mathrm{~g}$ & $20.21 \mathrm{i}$ & $22.10 \mathrm{~g}$ \\
Humic acid at $5 \mathbf{5 m l} / \mathbf{l}(\mathbf{A})$ & $13.24 \mathrm{~g}$ & $11.11 \mathrm{~g}$ & $51.24 \mathrm{f}$ & $58.19 \mathrm{f}$ & $21.99 \mathrm{~h}$ & $23.00 \mathrm{~g}$ \\
Humic acid at 10ml/I (B) & $15.72 \mathrm{f}$ & $15.62 \mathrm{f}$ & $64.54 \mathrm{~d}$ & $71.02 \mathrm{~d}$ & $25.21 \mathrm{~g}$ & $26.11 \mathrm{f}$ \\
Amino acid at $\mathbf{1 g} / \mathbf{p o t}$ (C) & $20.30 \mathrm{e}$ & $19.22 \mathrm{e}$ & $59.34 \mathrm{e}$ & $65.32 \mathrm{e}$ & $26.73 \mathrm{f}$ & $26.99 \mathrm{f}$ \\
Amino acid at 2g/pot (D) & $21.99 \mathrm{~d}$ & $21.99 \mathrm{~d}$ & $80.82 \mathrm{c}$ & $82.12 \mathrm{c}$ & $30.27 \mathrm{e}$ & $29.12 \mathrm{e}$ \\
A + C & $22.22 \mathrm{~d}$ & $25.33 \mathrm{c}$ & $87.50 \mathrm{~b}$ & $92.74 \mathrm{~b}$ & $35.00 \mathrm{~d}$ & $35.67 \mathrm{~d}$ \\
A + D & $24.31 \mathrm{c}$ & $27.20 \mathrm{~b}$ & $97.89 \mathrm{a}$ & $97.33 \mathrm{a}$ & $40.12 \mathrm{c}$ & $40.22 \mathrm{c}$ \\
B + C & $27.53 \mathrm{~b}$ & $28.00 \mathrm{~b}$ & $100.00 \mathrm{a}$ & $100.00 \mathrm{a}$ & $42.15 \mathrm{~b}$ & $42.31 \mathrm{~b}$ \\
B + D & $30.79 \mathrm{a}$ & $33.21 \mathrm{a}$ & $100.00 \mathrm{a}$ & $100.00 \mathrm{a}$ & $45.72 \mathrm{a}$ & $46.37 \mathrm{a}$ \\
\hline
\end{tabular}

Means within a column having the same letters are not significantly different according to Duncan's Multiple Range Test (DMRT) at 5\% level. 
Table 2. Effect of humic acid and amino acids on fresh and dry weights of plants/pot of Paspalum vaginatum Swartz. plants during 2014 and 2015 seasons.

\begin{tabular}{lcccc}
\hline \multicolumn{1}{c}{ Treatments } & \multicolumn{2}{c}{ Fresh weight (g) } & \multicolumn{2}{c}{ Dry weight (g) } \\
& $\mathbf{2 0 1 4}$ & $\mathbf{2 0 1 5}$ & $\mathbf{2 0 1 4}$ & $\mathbf{2 0 1 5}$ \\
\hline Control & $25.23 \mathrm{~g}$ & $28.11 \mathrm{i}$ & $11.24 \mathrm{~h}$ & $13.00 \mathrm{i}$ \\
Humic acid at 5ml/l (A) & $32.11 \mathrm{f}$ & $34.12 \mathrm{~h}$ & $14.30 \mathrm{~g}$ & $15.32 \mathrm{~h}$ \\
Humic acid at 10ml// (B) & $37.11 \mathrm{e}$ & $39.17 \mathrm{~g}$ & $17.95 \mathrm{f}$ & $18.02 \mathrm{~g}$ \\
Amino acid at 1g/pot (C) & $40.32 \mathrm{~d}$ & $44.32 \mathrm{f}$ & $18.73 \mathrm{ef}$ & $19.99 \mathrm{f}$ \\
Amino acid at $\mathbf{2 g} / \mathbf{p o t}$ (D) & $41.29 \mathrm{~d}$ & $51.21 \mathrm{e}$ & $19.23 \mathrm{e}$ & $23.21 \mathrm{e}$ \\
A + C & $44.31 \mathrm{c}$ & $54.00 \mathrm{~d}$ & $22.33 \mathrm{~d}$ & $25.10 \mathrm{~d}$ \\
A + D & $45.99 \mathrm{c}$ & $57.20 \mathrm{c}$ & $24.32 \mathrm{c}$ & $26.11 \mathrm{c}$ \\
B + C & $57.32 \mathrm{~b}$ & $59.34 \mathrm{~b}$ & $27.95 \mathrm{~b}$ & $28.00 \mathrm{~b}$ \\
B + D & $60.31 \mathrm{a}$ & $65.20 \mathrm{a}$ & $33.52 \mathrm{a}$ & $34.20 \mathrm{a}$ \\
\hline
\end{tabular}

Means within a column having the same letters are not significantly different according to Duncan's Multiple Range Test (DMRT) at 5\% level.

Table 3. Effect of humic acid and amino acids on pigments content (mg/100g F.W.) in the leaves of plants/pot of Paspalum vaginatum Swartz. plants during 2014 and 2015 seasons.

\begin{tabular}{lcccccc}
\hline \multirow{2}{*}{ Treatments } & \multicolumn{2}{c}{ Chlorophyll (a) } & \multicolumn{2}{c}{ Chlorophyll (b) } & \multicolumn{2}{c}{ Carotenoids } \\
& $\mathbf{2 0 1 4}$ & $\mathbf{2 0 1 5}$ & $\mathbf{2 0 1 4}$ & $\mathbf{2 0 1 5}$ & $\mathbf{2 0 1 4}$ & $\mathbf{2 0 1 5}$ \\
\hline Control & $1.20 \mathrm{~g}$ & $1.51 \mathrm{~g}$ & $0.72 \mathrm{i}$ & $0.79 \mathrm{~h}$ & $1.25 \mathrm{~g}$ & $1.47 \mathrm{f}$ \\
Humic acid at $\mathbf{5 m l} / \mathbf{l}$ (A) & $2.21 \mathrm{f}$ & $2.99 \mathrm{f}$ & $0.99 \mathrm{~h}$ & $0.93 \mathrm{~g}$ & $1.49 \mathrm{f}$ & $1.99 \mathrm{e}$ \\
Humic acid at 10ml/ (B) & $2.82 \mathrm{e}$ & $3.41 \mathrm{e}$ & $1.40 \mathrm{~g}$ & $1.49 \mathrm{f}$ & $2.10 \mathrm{e}$ & $2.46 \mathrm{~d}$ \\
Amino acid at $\mathbf{1 g} / \mathbf{p o t}$ (C) & $2.97 \mathrm{e}$ & $3.88 \mathrm{~d}$ & $1.52 \mathrm{f}$ & $1.60 \mathrm{e}$ & $2.20 \mathrm{e}$ & $2.59 \mathrm{~cd}$ \\
Amino acid at $\mathbf{2 g} / \mathbf{p o t}$ (D) & $3.81 \mathrm{~d}$ & $3.99 \mathrm{~cd}$ & $1.62 \mathrm{e}$ & $1.78 \mathrm{~d}$ & $2.73 \mathrm{~d}$ & $2.54 \mathrm{~d}$ \\
A + C & $3.91 \mathrm{~d}$ & $4.20 \mathrm{c}$ & $1.70 \mathrm{~d}$ & $1.79 \mathrm{~d}$ & $2.86 \mathrm{c}$ & $2.73 \mathrm{c}$ \\
A + D & $4.32 \mathrm{c}$ & $4.98 \mathrm{~b}$ & $1.89 \mathrm{c}$ & $1.97 \mathrm{c}$ & $2.89 \mathrm{bc}$ & $2.73 \mathrm{c}$ \\
B + C & $4.80 \mathrm{~b}$ & $5.00 \mathrm{~b}$ & $1.99 \mathrm{~b}$ & $2.31 \mathrm{~b}$ & $2.99 \mathrm{~b}$ & $2.93 \mathrm{~b}$ \\
B + D & $5.99 \mathrm{a}$ & $6.22 \mathrm{a}$ & $2.43 \mathrm{a}$ & $2.45 \mathrm{a}$ & $3.72 \mathrm{a}$ & $3.29 \mathrm{a}$ \\
\hline
\end{tabular}

Means within a column having the same letters are not significantly different according to Duncan's Multiple Range Test (DMRT) at 5\% level.

as well as indoles and phenols content (mg/100 g f.w.) in the two seasons (Table, 4). The highest values were obtained from the combined treatments with humic acid as a foliar spray at $10 \mathrm{ml} / \mathrm{l}+$ amino acids as soil drench at $2 \mathrm{~g} / \mathrm{pot}$.

This may refer to the role of humic acid in supplying the plants with some nutrients necessary for healthy growth (Higa and Wididana, 1991). Also, amino acids as a buffer on the biosynthesis of other organic compounds i.e. pigments, vitamins, alkaloids, enzymes, coenzymes (Goss, 1973 and Kamar and Omar, 1987).

Briefly, to obtain the best growth and highest quality from commercial point of view, it is recommended to fertilize the plants with humic acid at $10 \mathrm{ml}+2 \mathrm{~g} /$ pot as a soil drench from amino acids 6 times with one month interval during growing season proved planting them in a sand.

\section{REFERENCES}

Abd El-Aziz, N.G.; Mahgoub, M.H. and Mazhar, A.M. (2009). Physiologal effect of phenylalanine and treptophan on the growth and chemical constituents of Antirrhinum majus plants.Ozean J. Applid Sciences, 2:399-407.

A.O.A.C. (1990). The Association of Official Agricultural Chemists. $15^{\text {th }}$ Ed., Arlington, Virginia, 22201:877-878.

Bettoni, M.M.; Gumpl, E.K.; Cuquel, F.L. and Mogor, A.F. (2009). Response of Kalanchoe plants to plant growth 
Boshra A. El-Sayed et al.

Table 4. Effect of humic acid and amino acids on total sugars, indoles and phenols content in the leaves of plants/pot of Paspalum vaginatum Swartz. plants during 2014 and 2015 seasons.

\begin{tabular}{|c|c|c|c|c|c|c|}
\hline \multirow[t]{2}{*}{ Treatments } & \multicolumn{2}{|c|}{$\begin{array}{c}\text { Total sugars } \\
(\%)\end{array}$} & \multicolumn{2}{|c|}{$\begin{array}{c}\text { Indoles } \\
\text { (mg/100g F.W.) }\end{array}$} & \multicolumn{2}{|c|}{$\begin{array}{c}\text { Phenols } \\
\text { (mg/100g F.W.) }\end{array}$} \\
\hline & 2014 & 2015 & 2014 & 2015 & 2014 & 2015 \\
\hline Control & $2.72 \mathrm{~g}$ & $4.99 \mathrm{~g}$ & $0.32 \mathrm{~g}$ & $0.41 \mathrm{~g}$ & $0.04 \mathrm{~b}$ & $0.03 \mathrm{c}$ \\
\hline Humic acid at $5 \mathrm{ml} / \mathrm{l}$ (A) & $5.99 \mathrm{f}$ & $5.21 \mathrm{~g}$ & $0.39 \mathrm{f}$ & $0.49 \mathrm{f}$ & $0.05 \mathrm{ab}$ & $0.04 \mathrm{bc}$ \\
\hline Humic acid at $10 \mathrm{ml} / \mathrm{l}$ (B) & $6.09 \mathrm{f}$ & $5.99 \mathrm{f}$ & $0.40 \mathrm{f}$ & 0.49 ef & $0.06 \mathrm{ab}$ & $0.05 \mathrm{bc}$ \\
\hline Amino acid at $1 \mathrm{~g} / \operatorname{pot}(\mathrm{C})$ & $6.88 \mathrm{e}$ & $6.72 \mathrm{e}$ & $0.45 \mathrm{e}$ & 0.50 ef & $0.06 \mathrm{ab}$ & $0.05 \mathrm{bc}$ \\
\hline Amino acid at $2 \mathrm{~g} /$ pot (D) & $6.89 \mathrm{e}$ & $6.98 \mathrm{e}$ & $0.49 \mathrm{~d}$ & $0.52 \mathrm{e}$ & $0.06 \mathrm{ab}$ & $0.06 \mathrm{a}-\mathrm{c}$ \\
\hline$A+C$ & $7.97 \mathrm{~d}$ & $8.00 \mathrm{~d}$ & $0.62 \mathrm{c}$ & $0.58 \mathrm{~d}$ & $0.07 \mathrm{ab}$ & $0.06 \mathrm{a}-\mathrm{c}$ \\
\hline $\mathbf{A}+\mathbf{D}$ & $8.52 \mathrm{c}$ & $8.99 \mathrm{c}$ & $0.69 \mathrm{~b}$ & $0.62 \mathrm{c}$ & $0.07 \mathrm{ab}$ & $0.07 \mathrm{ab}$ \\
\hline $\mathbf{B}+\mathbf{C}$ & $9.73 \mathrm{~b}$ & $9.32 \mathrm{~b}$ & $0.72 \mathrm{~b}$ & $0.78 \mathrm{~b}$ & $0.07 \mathrm{ab}$ & $0.07 \mathrm{ab}$ \\
\hline $\mathbf{B}+\mathbf{D}$ & $11.24 \mathrm{a}$ & $11.99 \mathrm{a}$ & 0.93 a & 0.89 а & 0.08 a & $0.09 \mathrm{a}$ \\
\hline
\end{tabular}

Means within a column having the same letters are not significantly different according to Duncan's Multiple Range Test (DMRT) at 5\% level.

regulators. Revista Brasileira de Hort. Ornam., 15(2): 153-157.

Canaway, P.M. (1992). The effects of two root zone amendments on cover and playing quality of a sand profile construction for football. Journal of the Sports Turf Res. Inst., 68: 50-61.

Dorer, S.P. and Peacock, C.H. (1997). The effect of humate and organic fertilizer on establishment and nutrition of creeping bentgrass putting greens. Inter. Turfgrass Soc. Res. J., 8:437-443.

Duncan, D.B. (1955). Multiple range and multiple F-tests. J. Biometrics, 11:1-42.

El-Naggar, A.A.M.; Amani, I.A. and ElTony, F.H. (2013). Response of Longflorum X Asiatic Hybrid Lilium plant to foliar spray with some amino acids. Alex. J. Agric. Res., 58:197-208.

El-Sayed, Boshra A. and El-Shal, S.A. (2008). Effect of growing media and humic acid on Schefflera quality. J. Agric. Sci., Mansoura Univ., 33(1):371381.

El-Sayed, Boshra A.; Abdel Fattah, Gehan H. and El-Shal, S.A. (2008). Improvement of growth and quality of Tifway sod by actosol and biofertilizers.
J. Biol. Chem. Environ. Sci., 3(1):91102.

Goss, J.A. (1973). Amino Acid Synthesis and Metabolism, in Physiology of Plants and Their Cells. Porgamom Press, Inc. New York.

Hashish, K.L.; Eid, R.A.; Kandil, M.M. and Mazhar, A.AM. (2015). Study on various levels of salinity on some morphological and chemical compotion of Gladiouls plants by foliar spray with glutathion and thiamine. International J. Chem. Tech. Res., 9:334-341.

Herbert, D.; Philips, P.J. and Strange, R.E. (1976). Determination of total carbohydrates. Methods in Microbiology, 5(8):290-344.

Higa, T. and Wididana, G.N. (1991). Changes in the soil microflora induced by effective microorganisms. Proc. the $1^{\text {st }}$ Inter. Conf. Kyusei Nature Farming, U.S. Dept. Agric., Washington D.C., USA, p. 153-162.

Hunter, A. and Butler, T. (2005). Effect of humic acid on growth and development of Agrostis stolonifera grass in a sandbased root zone. Inter. Turfgrass Soci. Res. J., 10: 937-943. 
Huxley, A.; Griffiths, M. and Levy, M. (1992). The New Royal Hort. Society Dictionary of Gardening. The Stockton Press, New York, 257-Park Avenue South, NY 10010, USA. Vol. 3 (790 pp) and Vol. 4 (888 pp).

Kamar, M.E. and Omar, A. (1987). Effect of nitrogen levels and spraying with animal forte (amino acids salvation) on yield of cucumber and potatoes. J. Agric. Sci., Mansoura Univ., 12(4):900-907.

Kim, S.H.; Kwon, J.S.; Lee, S.K.; Park, Y.D. and Kim, D.S. (1991). Studies on the enumeration of soil microorganisms, physico-chemical properties and their relationship in the rhizosphere soils under continual floriculture. Research Reports of the Rural Development Administration, Soil\& Fertilizer, 33(3):111.

Mahdi, M.Z. (1953). The influence of management on botanical composition and quality of turf. Ph.D. Thesis, Fac. Agric., California Univ., Los-Angeles, USA.

Mead, R.; Curnow, R.N. and Harted, A.M. (1993). Statistical Methods in Agriculture and Experimental Biology, $2^{\text {nd }}$ Ed., Chapman \& Hall Ltd., London, 335 pp.

Moran, R. (1982). Formula for determination of pigments extracted with N,N-dimethyl formamide. Plant Physiol., 69:13761381.

Morton, J.F. (1974). Salt tolerant sitt grass (Paspalum vaginatum Swartz.). Proceeding of the Florida State, Hort. Soc., Miami Univ., USA, 86: 482-490.

Muller, S.R. and Kussow, W.R. (2005). Biostimulants influences on turfgrass microbial communities and creeping bentgrass quality. HortScience, 40(6):1904-1910.

Philips, I.D.J. (1971). Introduction to the Biochemistry and Physiology of Plant Growth Hormones. MC. Growth-Hill Bock Company.

Russel, R.S. (1982). Plant Root Systems $1^{\text {st }}$ Ed. ELBS, UK., p. 17-18.

SAS Program (1994). SAS/STAT User's Guides Statistics. Vers. 6.04, $4^{\text {th }}$ Ed., SAS Institute Inc., Cary, N.C., USA.

Smith, T.A. (1982). The function and metabolism of polyamines in higher plants. In. Wareing P.F. (Ed.). Plant Growth Substances, Academic Press, New Work.

Walter, G.R. and Nawacki, E. (1987). Alkaloids Biology Metabolism in Plants. Planum Press, NY. 152 pp.

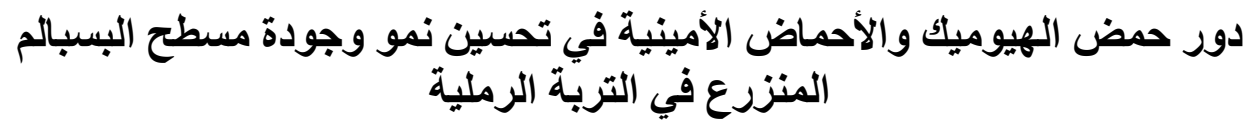


Boshra A. El-Sayed et al.



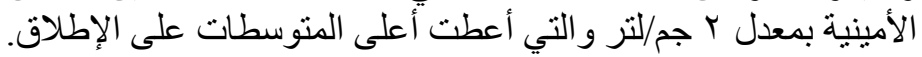

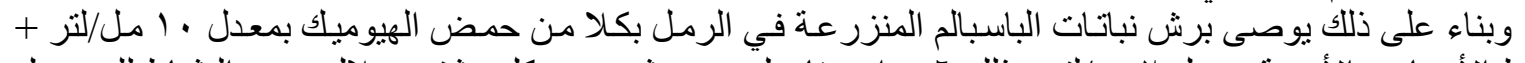

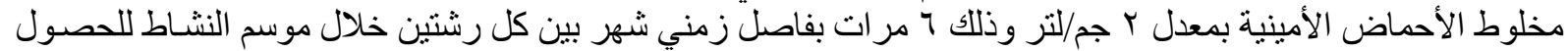
على أفضل نمو وأعلى جودة. 